SANDFORD, K. S., 1954. The geology of Isis Point, North-East Land (Spitsbergen). Quart. J. geol. Soc. Lond., 110, 11-20.

1956. The stratigraphy and structure of the Hecla Hoek Formation and its relationship to a subjacent metamorphic complex in NorthEast Land (Spitsbergen). Quart. J. geol. Soc. Lond., 112, 339-362.

1963. Exposures of Hecla Hoek and younger rocks on the north side of Wahlenbergfjorden, Nordaustlandet (Svalbard). Norsk Polarinst. Arbok, 1962, 7-23.

Tyrrell, G. W., 1924. The Geology of Prince Charles Foreland, Spitsbergen. Trans. roy. Soc. Edinb., 53, Part 2 (23), 443-478.

Wallis, R. H., W. B. Harland, D. G. Gee, and R. A. Gayer. (In preparation.) Petrographic nomenclature of Metamorphosed Hecla Hoek Rocks in Spitsbergen. Norsk Polarinst. Arbok.

Wenx, E., 1961. On the Crystalline Basement and the Basal Part of the PreCambrian Eleonore Bay Group in the South-western Part of Scoresby Sund. Medd. Gronland, Bd. 168 (1).

Wilson, C. B., 1958. The Lower Middle Hecla Hoek rocks of Ny Friesland, Spitsbergen. Geol. Mag., 95 (4), 305-327.

1961. The Upper Middle Hecla Hoek rocks of Ny Friesland, Spitsbergen. Geol. Mag., 98 (2), 89-116.

and W. B. Harland, 1964. The Polarisbreen Series and other evidences of Late Pre-Cambrian Ice Ages in Spitsbergen. Geol. Mag., 101 (3), 198-219.

Winsnes, T. S. (In press.) The Precambrian of Spitsbergen and Bjørnøya. In The Geologic Systems. The Precambrian, Vol. 2. Edit. K. Rankama. Interscience Publishers (John Wiley and Sons), London.
W.B.H. AND R.H.W.,
DePARTMENT OF GEOLOGY,
SeDGWICK Museum, CAMBridge.

\author{
R.A.G., \\ DePARTMENT OF GeOLOGY, \\ UNIVERSTTY COLLEGE, \\ Cathays Park, \\ CARDIFF.
}

\title{
CORRESPONDENCE
}

\section{STRATIGRAPHIC CLASSIFICATION AND TERMINOLOGY}

SIR,-As geologists working in the Jurassic System we wish to comment on the article by H. D. Hedberg (Geol. Mag., 102, 451-461) which is devoted to criticizing, amongst others, papers arising from the Luxembourg Colloquium on the Jurassic held in 1962.

The point at issue is the distinction between biostratigraphical and chronostratigraphical units. Dr. Hedberg finds it hard to understand how anyone can fail to see the distinction. The point is that the theoretical distinction is *ar enough, but we think it is unimportant. Biostratigraphical units are bodies of strata defined by the presence of one or more fossil species, and are therefore directly observable quantities. Their importance is that some of them, properly chosen, are believed to have boundaries which approximate to being isochronous. Chronostratigraphical units are defined as bodies of strata formed during a specific interval of geological time, and hence are not directly observable quantities. They must be defined in terms of e.g. biostratigraphical units in a type section. Both kinds of units are easy to define, but we must distinguish clearly between the problems of definition and of recognition. We contend that a stratigraphical unit that cannot be recognized at places other than where it is defined is of little value. As Dr. Hedberg points out, the boundaries of chronostratigraphical units are everywhere independent of all rock characters, including fossils, but of what value is this 
if there is no way of determining where they lie? Therefore the recognition of chronostratigraphical boundaries can only be as good as that of biostratigraphical units which they are thought to encompass. In defining chronostratigraphical units one must, therefore, choose, if one can, biostratigraphical units which approximate to them over the greatest distances. Dr. Hedberg stresses the importance of other means of proving time-equivalence-bedding planes locally, and radiometric dating-but no-one would to-day define Phanerozoic stages etc. in such terms.

Dr. Hedberg says that the Luxembourg Colloquium defined stages (chronostratigraphical units according to the Copenhagen Statement of Principles, Hedberg, 1961) in terms of biostratigraphical zones, but this was not stated by Ager (1963) whom he quotes. The zones are in fact examples of "Standard Named Chronostratigraphical Units" (Copenhagen Statement, section D8, p. 28). The terms zone and stage have been used in this sense in the Jurassic since Oppel's time, and the object of Jurassic stratigraphers has been to construct a standard sequence of zones and stages (Arkell, 1946, p. 3). The units of such a scheme form a hierarchy and are of a special type (Callomon, 1965). They are subject to the requirements of contiguity (no gaps, no overlaps) and common boundaries (boundaries between larger units must always coincide with boundaries between smaller units, down to the smallest). While a standard hierarchy was mentioned in the Copenhagen Statement practice in the Jurassic has always gone beyond this in two respects : (1) the contiguity requirement is extended down to zones, and (2) the common boundaries requirement, not mentioned in the Statement, is assumed. This means that typological definition must be at the lowest level, here the zone, and that larger units (stages) must be defined in terms of smaller ones. We cannot, therefore, follow Dr. Hedberg and the Copenhagen Statement in defining standard stages independently by type sections.

Such standard stratigraphical scales can only be constructed and are only useful if units with isochronous boundaries can be widely recognized in the field. As Dr. Hedberg points out, this may not be possible in general ; but this does not mean that it is never possible, and the special feature of standard Jurassic ammonite zones is that they have been carefully arranged to be zones which are both chrono- and biostratigraphical units, not only in one typesection, but over large areas. The Jurassic may be particularly fortunate in its fossils ; but surely all stratigraphers concerned with zoning by fossils work towards the same end ? Thus, the distinction between chrono- and biostratigraphical units is, in the case of standard zones, not as obvious as Dr. Hedberg would have us believe, and above all, is not important. The same considerations apply to standard stages, which defined as at Luxembourg as groups of standard zones, cannot differ qualitatively from the latter.

Finally, there is nothing peculiar in the proposal to define standard stratigraphical units by their bases only. This is forced upon us by the requirement of contiguity. To say that units should only be defined " in a section where deposition had presumably been continuous" is unrealistic. New discoveries are constantly proving the incompleteness of successions previously thought to be continuous. Dr. Hedberg correctly supposes that the definition of the base automatically fixes the top of the unit beneath. So it does-until someone somewhere discovers a fauna which is older than the defined base and younger than the "automatically fixed" top. Provided that bases only are defined such a fauna automatically belongs to the lower unit and there can be no dispute as to its allocation.

It appears, therefore, that misunderstandings have arisen because the words zone and stage as used, unqualified, by Oppel and Jurassic workers since have the meanings Standard Named Zone, Standard Named Stage in the terminology of Dr. Hedberg and the International Subcommission. The only question which remains is whether the words should be qualified in one or both meanings, and if so, which and how? In the Jurassic literature the meaning "standard zone" is usually obvious from the context, which is why almost no-one has ever bothered to qualify it. Arkell (1956) pressed for the 
typographical indication of [standard] zones, e.g. Plicatilis Zone Hudleston, 1878 , index Am. plicatilis J. Sowerby, 1817, means Standard Named Zone of Am. plicatilis J. Sowerby, 1817 , proposed by Hudleston in 1878 . "Zone of Am. plicatilis" could be regarded as ambiguous, as Dr. Hedberg says ; "Plicatilis Zone" according to the convention here used, is not, and the convention could be generally adopted for naming standard zones.

\section{REFERENCES}

AGER, D. V., 1963. Jurassic stages. Nature, Lond., 198, 1045-6.

ARKELl, W. J., 1946. Standard of the European Jurassic. Bull. geol. Soc. Amer., 57, 1-34.

1956. Comments on stratigraphic procedure and terminology. Amer. J. Sci., 254, 457-467.

Callomon, J. H., 1965. Notes on Jurassic stratigraphical nomenclature. I. Principles of stratigraphic nomenclature. Carpatho-Balkan Geol. Ass., VII Congress, Sofia, Sept., 1965. Reports, Part ii, 1, 81-5.

Hedberg, H. D., (editor), 1961. Stratigraphic Classification and Terminology. (Report of the International Subcommission on Stratigraphic Terminology). Rep. XXI Intern. Geol. Congr., Norden, 1960, part 25. Copenhagen.

J. H. Callomon.

UNIVERSITY COLLEGE, LONDON.

THE UNIVERSITY, HULL.

11th January, 1966.

D. T. Donovan.

\section{REVIEW}

United States Geological Survey. Professional Paper 525-B. Geological Survey Research, 1965, Chapter B. Pp. vi +195 , figures, maps, tables. U.S. Government Printing Office, Washington, 1965. Price \$1.75.

The first part of Professional Paper 525 to be issued is a collection of fortyone original papers, in part giving results of completed portions of continuing researches, in part announcing new discoveries of preliminary results. Publication of the full results of Survey investigations suffers from considerable delay in many countries, and this method of advanced statement of some of the results is very much to be welcomed. The subjects covered illustrate the wide scope of U.S.G.S. research activity : geophysics, economic geology, structural and stratigraphic geology, palaeontology, petrology, geochemistry, geomorphology, glaciology, physical properties of rock, analytical techniques : there is hardly a field unrepresented. A major section is devoted to four papers on hydrology and there is also an interesting article, from the Publications Division, on photographic copying using reflectiontransmission illumination.

It is impossible to review more than a few of the papers, and the reader will quickly realize that the selection made here is based on personal interest.

L. C. Pakiser's discussion of the basalt-eclogite transformation in relation to the crustal structure of the Western United States is outstanding in the suggestion that here the generally accepted view, that the crust is thin in stable continental regions and thick in orogenic belts, cannot be applied ; the seismic evidence recently obtained by U.S.G.S. geophysical parties indicates that the reverse is the case. The Rocky Mountains belt separates the Great Interior Plains to the east from the Basin and Range province to the west. In the former, the Mohorovicic discontinuity everywhere lies more than $40 \mathrm{~km}$. 